\title{
早期胃癌の平面上での進展に関する研究
}

\author{
東京医科歯科大学医学部第 2 外科学教室 \\ 化瓶善郎宮永忠彦平山廉三 \\ 浅 野 献一
}

\section{STUDIES ON THE SPREADING PATTERN OF EARLY GASTRIC GANCER IN THE MUCOSAL LAYER}

Zenro NIHEI, Tadahiko MIYANAGA, Renzo HIRAYAMA and Ken-ichi ASANO

The 2nd Department of Surgery, Tokyo Medical and Dental University, School of Medicine

早期胃癌の表面扗大と深澾度に関する報告は多いが，粘膜面での進展方向に関するすの は少ないそこで, 教室で経験した早期胃癌89例98病巣を分析し，早期胃癌の 2 次元での 進展方向について検討を加えた結果，以下の結論を得た。なお，長径 $2.0 \mathrm{~cm}$ 以上，長径 短径比2.0以上の病巣を,「長棈円病巣」とした.

1） 98病巣中77病巣 $(78.6 \%)$ は，長短比 2.0 未満であり，早期胃癌はほぼ同心円状に 発育する.

2）長棈円病巣は16病巣 $(16.3 \%)$ であり，横軸方向に優勢であった．Cにはなく，混 合型に出現率が高かったが，肉眼型との関係は認められなかった．漬瘍病変を有するもの が然らざるものの約 2 倍であった。

3）幽門輪に接して発育するものは，粘膜層で幽門輪を越えることがあるが，その綎軸 方向への発育は幽門輪で抑制され，横軸方向への拡がりが著明となる.

\section{1. 緒言}

早期胃癌の進展方向については，今迄に多くの報告が なされているが，その主たる内容は，表面払大と深達度 に関するるの，即ち水平方向と垂直方向への進展の関連 についてであり, 粘膜面における進展方向, 即ち 2 次元 での進展に関するむのは少ない.

最近我々は, 幽門輪に接し, 早期胃癌としては稀な全 周性に発育した，即ち胃の綖軸方向に比し横軸方向へ著 しく発青した I c + III型早期胃癌症例を経験した.

そこで，早期胃癌の 2 次元での進展方向，即ち同心円 状に拡がるか，あるいは方向性をもって棈円乃至線状に 払がるかについて検討することは興味ある問題であると 考え，教室で経験した早期胃癌89例98病巣を対象とし， 早期胃癌の 2 次元での進展方向について検討を加えたの で報告する.あわせて全周性発育を呈した早期胃癌の 1 例の概要を供覧する.

\section{2. 検索対象およひ方法}

1968年より1977年迄の10年間に教室で経験した早期胃 癌89例98病巣（但 L, 進行癌と重複せる早期胃癌病巣は 除外した））を今回の検索対象とした。男性65例，女性 24例, 平均年龄は57.2歳であった. 深達度は, 粘膜内に

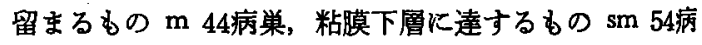
巣であった。

病巣の拡がりを決めるあたり，切除胃を大網前壁奇り で開き，自然な状態に伸展し，10\%ホルマリン固定し たものについて，5mm 幅の切りたしを行ない組織学的 に粘膜面での病栄の範团を決定した. 即ち, sm 症例に は，粘膜下層の病巣範囲が粘膜層のそれよりる著しく小 さいものも認められたがここれらは粘膜層の拡がりを病 巣の执がりとした。

粘膜層での進展様式の尺度として, 病巣の長径と短径 との比(以下，長短比)を用いた.ささらに，長短比2.0以 
表 1 早期同露の执がり：長经と長短比との関係 （）:sm

\begin{tabular}{|c|c|c|c|c|c|c|c|c|c|}
\hline $\begin{array}{l}\text { 長短比 } \\
\text { 長柊 } \\
\text { (cm) }\end{array}$ & 1.5未満 & $1.5 \sim$ & $2.0 \sim$ & $2.5 \sim$ & $3.0 \sim$ & $3.5 \sim$ & $4.0 \sim$ & 4.5 以上 & 計 \\
\hline 2.0 末満 & $16(3)$ & $66(2)$ & $2(0)$ & $2(0)$ & & & & $1(0)$ & $\begin{array}{l}27(5) \\
27.6 \%\end{array}$ \\
\hline 2.0 & $24(15)$ & $11(3)$ & $6(3)$ & $4(2)$ & & & & & $\begin{array}{l}45(23) \\
45.9 \%\end{array}$ \\
\hline 4.0 & $9(8)$ & $3(1)$ & $1(0)$ & $1(0)$ & & & & & $\begin{array}{l}19(9) \\
19.4 \% \\
\end{array}$ \\
\hline 6.0 & $2(2)$ & $3(1)$ & & & $1(0)$ & $1(0)$ & & 1 (1) & $\begin{array}{l}8(4) \\
8.2 \%\end{array}$ \\
\hline 8.0以上 & $2(2)$ & $1(1)$ & & $1(1)$ & & & & & $\begin{array}{l}4(4) \\
4.1 \%\end{array}$ \\
\hline 計 & $\begin{array}{r}53(30) \\
54.1 \% \\
\end{array}$ & $\begin{array}{r}24(8) \\
24.5 \%\end{array}$ & $\begin{array}{c}9(3) \\
9.2 \%\end{array}$ & $\begin{array}{l}8(3) \\
8.2 \%\end{array}$ & $\begin{array}{l}1(0) \\
1.0 \%\end{array}$ & $\begin{array}{l}1(0) \\
1.0 \%\end{array}$ & & $\begin{array}{l}2(1) \\
2.0 \%\end{array}$ & $\begin{array}{r}98(45) \\
100 \% \\
\end{array}$ \\
\hline
\end{tabular}

上, 長径 $2.0 \mathrm{~cm}$ 以上の病巣を「長棈円病巣」として扱 い, 「長棈円病巣」の特徵を, 占居部位, 組織型, 肉眼 型站よび潰瘄病变の有無の 4 項目から検討した。

\section{3. 耛 果}

1) 病紧の搪がり：病巣の拡がりは, 表 1 に示寸如 く, 長短比 1.5 未満の のが 53 病巣 $(54.1 \%)$ と半数以 上を占め最 も多之, 以下, 1.5 以上 2.0 末満 24 病笨 (24.5 $\%), 2.0$ 以上 3.0 未満 17 病巣 (17.3\%) 3.0以上 4 病巣 (4.1\%)と長短比が大きくなるとつれてその頻度は減 少する傾向が認められた。 また，長径は $2.0 \mathrm{~cm}$ 以上 4.0 $\mathrm{cm}$ 末満のものが 45 病巣 $(45.9 \%)$ と最む多かった．長 棈円病巣は16病巣 (16.3\%) であった。

なお，病巣の抾がりと深達度との関係を，長径と sm 病单の頻度によりみると, sm 病巣は, 長径 $2.0 \mathrm{~cm}$ 末 满では27病巣中 5 病巣 $(18.5 \%)$ と少なく，以下 $2.0 \mathrm{~cm}$ 以上 $4.0 \mathrm{~cm}$ 末満 45 病巣中 23 病巣 $(51.1 \%) 4.0 \mathrm{~cm}$ 以上 $6.0 \mathrm{~cm}$ 末満 19 病巣中 9 病巣 $(47.4 \%), 6.0 \mathrm{~cm}$ 以上 8.0 $\mathrm{cm}$ 末満 8 病巣中 4 病巣 $(50.0 \%) 8.0 \mathrm{~cm}$ 以上では 4 病 巣中 4 病巣 (100\%) であった。

2）進展方向：進展方向については，表 2 に示す如 く，胃の小弯に平行な拗がりを綖軸，それ直角方向一

表 2 早期胃密の進展方向

\begin{tabular}{|c|c|c|c|c|}
\hline 靖展方向 & $\begin{array}{l}\text { 擭粙方向 } \\
\text { ヘの搪がリ }\end{array}$ & $\begin{array}{l}\text { 证刺方向 } \\
\wedge の \text { 掋がり }\end{array}$ & \multicolumn{2}{|c|}{ 検め方向への拡がり } \\
\hline 惯式四 & & & & \\
\hline 屚果数 & 13 & 1 & 1 & I \\
\hline
\end{tabular}

表 3 長棈円病釆の進展方向と局在との関係

\begin{tabular}{|c|c|c|c|c|c|c|c|}
\hline \multirow{2}{*}{ 病柴 } & \multicolumn{5}{|c|}{ 長楕丹病莜 } & \multirow{2}{*}{ その他 } & \multirow[b]{2}{*}{ 計 } \\
\hline & $\longleftrightarrow$ & $\downarrow$ & $\swarrow$ & & 小 計 & & \\
\hline $\mathrm{C}$ & & & & & $0(0 \%)$ & 8 & 8 \\
\hline M & 7 & & 1 & 1 & $9(20.0 \%)$ & 36 & 45 \\
\hline A & 6 & 1 & & & $7(15.696)$ & 38 & 45 \\
\hline 計 & 13 & 1 & 1 & 1 & $16(16.39)$ & 82 & 98 \\
\hline
\end{tabular}

の拡がりを横軸方向への払がりとし，いずれにも属さな いむのを斜め方向への抎がりとした，長棈円病巣16病巣 の内訳は, 横軸方向 13 病巣, 䊓軸方向 1 病巣, 斜め方向 2 病巣であった.

3）局在との関保：病巣の主たる占居部位を胃癌取扱 い規約に従い分類すると，表 3 亿示す如く，C 8 病巣， M45病巣, A 45病巣であり, 小弯 43 病巣, 大弯10病巣, 前壁20病巣, 後壁24病巣, 全周 1 病巣であった。長棈円 病巣16病巣の内訳は, M9 病巣, A 7 病巣であり, Cに は認められなかった，M，Aでの長棈円病巣の出現頻度 は, M20.0\% (9/45), A 15.6\% (7/45) とMKやゃ高加 った.

4）組型との関係：病巣の組織型を，高分化型，混 合型，低分化型の 3 型に分類した．即ち，同一病巣内に 認められる組織型が, 高分化型のみで構成されているむ のを高分化型, 低分化型のみのるのを低分化型, その両 者が混在しているるのを混合型とすると，表 4 に示す如 く, 高分化型52病巣, 混合型27病巣, 低分化型19病巣で あった，長棈円病巣16病巣の内訳は，高分化型 7 病巣, 混合型 6 病巣, 低分化型 3 病坚で, 高分化型に最与多く みられたが，各組織型での出現頻度は，高分化型13.5\% 


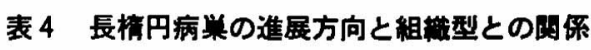

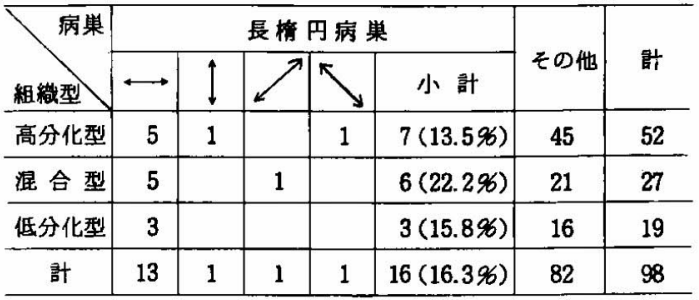

表 5 長棈円病栄の進展方向と肉眼型との閉係

\begin{tabular}{|c|c|c|c|c|c|c|c|}
\hline \multirow{2}{*}{ 肉眼型 } & \multicolumn{5}{|c|}{ 辰柽円病巣 } & \multirow{2}{*}{ その他 } & \multirow{2}{*}{ 計 } \\
\hline & $\longleftrightarrow$ & $\uparrow$ & & & 小計 & & \\
\hline 隆起型 & 3 & 1 & & 1 & $5(15.6 \%)$ & 27 & 32 \\
\hline 平坦型 & & & & & $O(0 \%)$ & 0 & 0 \\
\hline 陥凹型 & 10 & & 1 & & $11(16.796)$ & 55 & 66 \\
\hline 計 & 13 & 1 & 1 & 1 & $16(16.396)$ & 82 & 98 \\
\hline
\end{tabular}

(7/52), 混合型 $22.2 \%(6 / 27)$, 低分化型 $15.8 \%$ (3/19) で混合型で最も高かった．また，低分化型の 3 病巣はい ずれも横軸方向の拡がりを示していた。

5）肉眼型との関係 : 病巣の肉眼型を内視鏡学会によ る早期胃癌肉眼分類により分類し，これらを，隆起型， 平坦型, 陥山型に大別した. その内訳は，表 5 に示寸如 く, 隆起型32病巣, 陥凹型66病巣であり, 平坦型は認め られなかった，長棈円病巣16病巣の内訳は，隆起型 5 病 巣, 陥四型11病巣之陥凹性病変に多く認められたが, 各 肉眼型での㤕現頻度は，隆起型15.6\% (5/32), 陥凹型 16.7\% (11/66) とほぼ等しかった. 隆起型 5 病栄中横 軸方向の拡がりを示すものは 3 病巣, 縦軸方向, 斜め方 向の拡がりを示すものが各々 1 病巣 つつであるのに対 乙，陷凹型では11病巣中10病巣が横軸方向への払がりを 示していた.

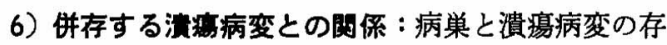

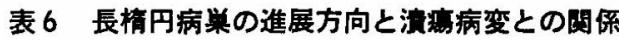

\begin{tabular}{|c|c|c|c|c|c|c|c|}
\hline \multirow{2}{*}{ 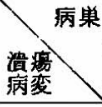 } & \multicolumn{5}{|c|}{ 長棈円病果 } & \multirow{2}{*}{ その他 } & \multirow[b]{2}{*}{ 計 } \\
\hline & $\longleftrightarrow$ & $\uparrow$ & & & 小 計 & & \\
\hline$(-)$ & 3 & 1 & 1 & 1 & $6(13.0 \%)$ & 40 & 46 \\
\hline Ul II & 4 & & & & $4(20.0 \%)$ & 16 & 20 \\
\hline U1 III & 4 & & & & $4(20.0 \%)$ & 16 & 20 \\
\hline UI IV & 2 & & & & $2(16.7 \%)$ & 10 & 12 \\
\hline 計 & 13 & 1 & 1 & 1 & $16(16.3 \%)$ & 82 & 98 \\
\hline
\end{tabular}

在との関保は，表 6 に示す如く, 併存する潰痬病変を認 めないむの46病巣, U1 II を伴うもの20病巣, U1 III伴 らもの 20 病巣, U1 IVを伴うすの12病巣であった（（但 し, 潰瘍的痕病巣を含む.) 長棈円病巣16病巣について 分析すると, 潰㾤病変を伴わないるの6 病巣, UI Iを 伴うもの 4 病巣, 以下, U1 II 4 病巣, Ul IV 2 病巣で,

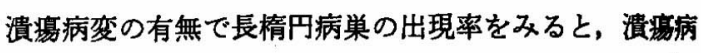
変の無いるのでは13.0\%(6/46), 有するものでは19.2\% (10/52) であり，また長桍病巣の62.5\% (10/16) か蛽 湟病変を併存していた。 なお, 潰瘍病変を伴らすのは, 全て横軸方向の拡がりを示していた。

\section{4. 症例}

以上，教室に批る早期胃癌の 2 次限での進展方向に ついて分析を加えたが，長棈円病巣中，幽門輪に接し， 早期胃癌としては稀な 全周性の 発育を呈したII c十II型 早期胃癌症例があったのでその概要を呈示する.

症例は, 71歳男性で, 黒色便を主訴として来院した. 家族歴：父，兄が胃癌にて死亡.，既往歴：56歳，肺結核 飞て 1 年間入院. 入院時, 理学的所見では, 心简部に抵 抗を認める以外異常を認めなかった。胃液：低酸，写充 1 亿示す如く，幽門部に en face の niche を認め,胃内 視鏡所見にては，写真 2 に示寸如く，幽門前庭部の大弯

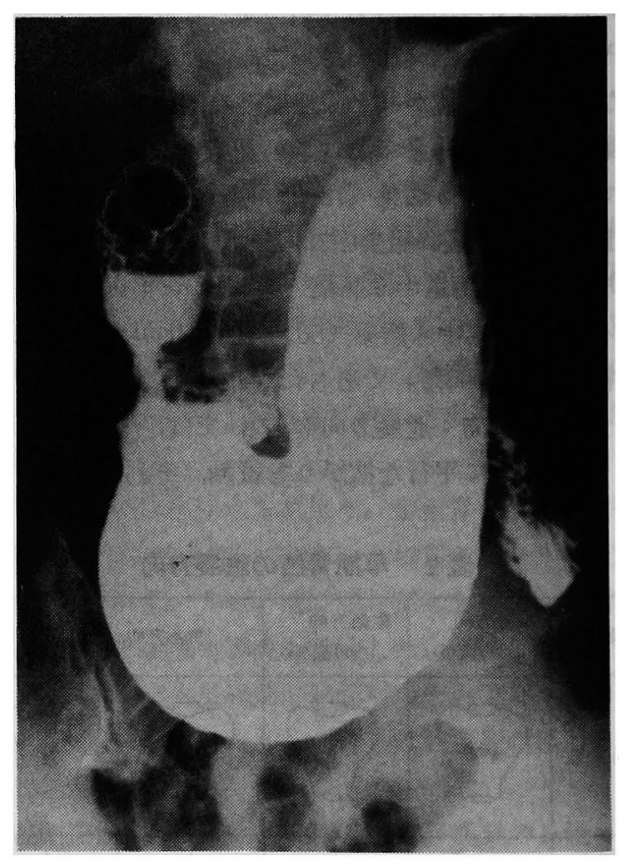

写重 آ胃透視所見 


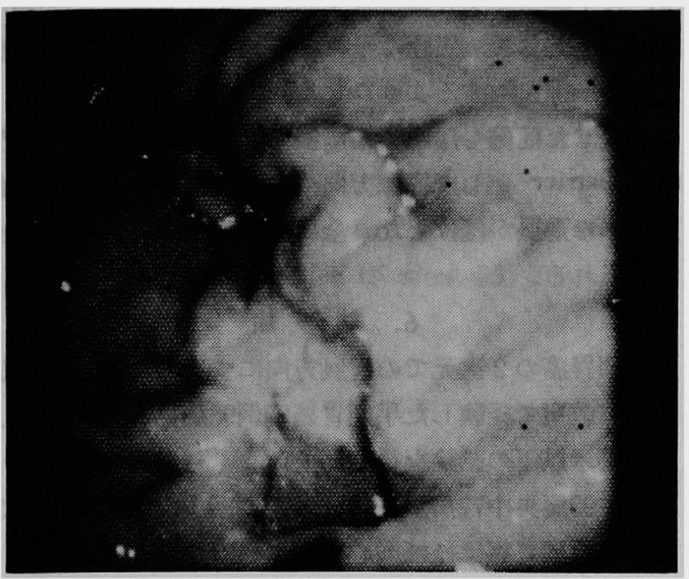

写基 2 胃内視鏡所見

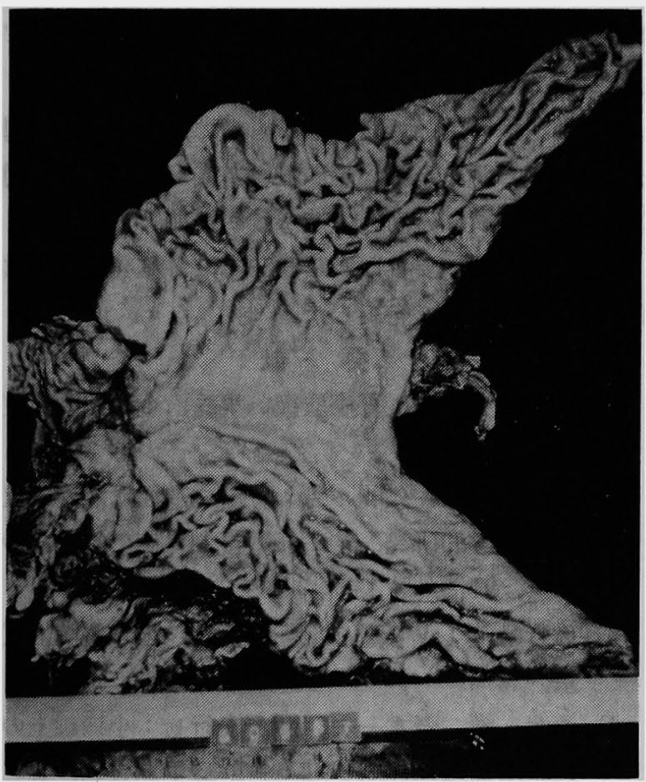

写來 3 切除標本

を中心としたII c+III病変を認めた。生検では group Vであった。 手術所見：胃切除術B-I， $\mathrm{R}_{2}$. A 周 $\mathrm{P}_{0} \mathrm{H}_{0}$ $\mathrm{N}_{\mathrm{l}}$. 病理所見 : 切除標本は, 写真 3 K示す如 $<$, 幽門輪 に接した 全周性 II c+II病変でであり，その病変の幅は $1.0 \mathrm{~cm}$ であった. 組織学的には, 写真 4 に示す如く, 低 分化型腺癌であり，深達度 smの早期胃癌であった. な お，腫場肛門側は，その粘膜面において，極一部分のみ が十二指腸へ僅かに漫潤していた. INF $\gamma, \mathrm{ly}_{1}, \mathrm{v}_{0}, \mathrm{n}_{0}$.

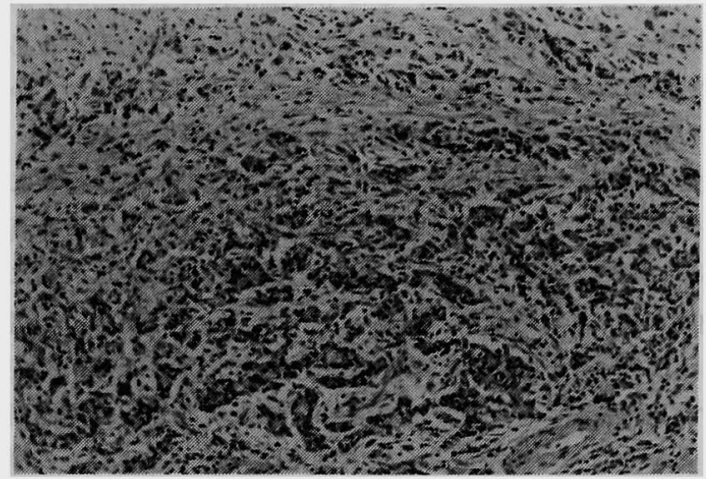

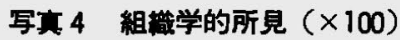

\section{5. 考按}

早期胃癌の進展, 殊に病巣の粘膜面での拡がりと深達 度に関しては既に多くの報告がなされているが，粘膜面 での病巣の抝がりについての報告は少ない，我々は，教 室で経験した早期胃癌症例の粘膜面での進展方向につい て分析し検討を加え， 2,3 の知見を得た.

検索には，ホルマリン固定した組織標本を用いたが， 村田 ${ }^{2}$ らの報告によれば，固定による収縮率は，横方向 1.064, 縦方向 1.081 であり，ほぼ相似形に雨みなく縮小 しているすのと考えられる.

一般に, 早期胃癌の粘膜面での抾がりは，多少の辺縁 の不正はあっても，ほぼ円形かあるいは円形に近い棈円 形であるが，我々の症例です，長短比 2.0 以下のすのが $78.6 \%(77 / 98)$ を占め, 極端に細長い病巣は少ないこ とが認められた. 勿論長短比 2.0 以上のものでも病巣が 此較的小さなるのでは, 切除されずに発育した場合，そ の形がどの上うに変化するか予想し得ないため，今回の 研究では, 長径 $2.0 \mathrm{~cm}$ 以上, 長短比 2.0 以上の病巣を長 棈円病巣とした。

佐野了は，潰場を伴う早期胃癌の粘膜内進展方向を検 討し，長短比についてはふれていないか，潰瘍を中心と 乙て横軸方向に抾がるものが最も多いとしている. 我々 の症例です長棈円病巣の進展方向は横軸方向が最も多 く，絽軸方向は 1 例のみであった．著者らが調查し得た 範囲では, 西沢ら“が報告した症例に綐軸方向に著しく 進展した早期胃癌病巣をみるのみである.

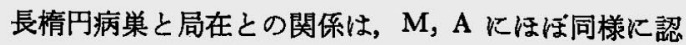
められたが，Cには 1 例も認められなかった。低分化型 に長棈円病巣が少なく，M，A に打いて低分化型の出現 率が低いことにも関連があるとも考えられるが，組織型 
と局在との関保からは，Cにも理論的には長棈円病巣が 期待し得る. Cに和ける解剖学的特性 む考虑に入れる必 要があると考学る所以であるが，更に症例を経験してか ら検討を重执たい，長楕円病巣と組織型 との関係は， 先述の如く，低分化型にその出現率が低く，高分化型に やや高いが，混合型に扣いて，両者の約 2 倍と最も高 率に認められる．現在，胃癌病理組織分類では一般に predominant な組織型をるって代表させているが，著者 $5^{5)}$ は, 同一病巣内に高分化型, 低分化型の組織方混在 する混合型に注目すべきであると考えており，長棈円病 巣るその一つの特徵としてあげることがでさよう，長棈 円病巣と肉眼型との関係は，隆起型と陥凹型の間㶤著差 を認めなかった．長榜円病巣と潰煌病変との関係は， 潰場病変と有する長惰円病巣が然らざるむのの 2 倍であ り，また，潰瘍病变を伴う病巣に括ける長棈円病巣の出 現率が，伴わない病巣に拟ける出現率よりるやや高く， 潰瘍を有する病巣は，長棈円病巣になりやすい傾向を示 している。村上のは，潰啺がなくて，がんたけが線状に 分布していることはまず見かけないとしており，我々の 分析においても長棈円病巣は漬瘍との共存率が高いが， 長棈円病巣の長短比を 2.0 以上とした場合，必ずしも長 楕円病巣が潰瘍を伴っているとは断言し得ないようであ る.

さて，全国胃がん 登録調查 ${ }^{7}$ によると，占居部位が

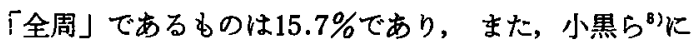
よれば, pm 胃癌のうち全周性病変を呈するものはAの みにみられ，その頻度は $7.1 \%$ あるとしているが，早 期胃癌で全周性の発育を認めたとする報告は，著者らの 啮椫し得た範围では，その一部が断裂しているものを含 めても極めて稀である ${ }^{910)}$ ．我々の経験した長棈円病巣 のうち 1 例が，幽門輪に接した 全周性病変を呈してい た.

一病巣が幅狭く全周性に発育するためには，緃軸方向 よりむ横軸方向への拗がりが極めて早いか，逆に綐軸方 向への進展が何らかの機転により阻止されることが必要 である. 1861年, Rokitansky"1) は，幽門輪を越之て癌后 が十二指腸へ進展することはないとしたが， Brinton ${ }^{12}$ の報告以来，かなり高率に十二指腸進展例を認めるよう である. その進展様式についてる，粘膜層については連 続性に浸潤する様式があるとするもの ${ }^{13)}$ ，また，粘膜固 有層を横へ進展することはないとするるのいががある が，いずれにせよ，粘膜層を連続破塄性に進展してもそ の距離は短かいとしている。また石川い゙は「「幽門上
で，胃十二指腸境界部にまで癌腫が発育した場合には， 最終段階として，癌腫は平行位に隣接し，十二指䖲固有 粘膜と一線を画するよらになる.」としている。

供筧した症例む，幽門輪に接して発生した澓腫が幽門 輪を barrier として縦軸方向への進展抑制をうけ，横軸 方向への進展が優位となり全周性病変を形成したすのと 考穴られる.

\section{6. 結 論}

早期胃癌の 2 次元での進展方向についての知見を得る ため, 教室で経験した早期胃癌89例98病巣を分析検討し た結果, 以下の結論を得た。

1） 98病巣中77病巣 $(78.6 \%)$ は，長短比 2.0 末満で あり，早期胃癌はほ注同心円状に発育する。

2）長径 $2.0 \mathrm{~cm}$ 以上, 長短比 2.0 以上の長棈円病巣は 16病巣 (16.3\%) であり，横軸方向に優勢であった．C になく，混合型に出現率が高かったが，肉眼型との関係 は認められなかった．潰瘍病变を有するものが然らざる むのの約 2 倍であった.

3）幽門輪に接して発育するものは，粘膜㿉で幽門埨 を越えることがあるが，その綎軸方向への発育は幽門陯 で抑制され，横軸方向への拡がりが著明となる。

なお，本論文の要旨は，昭和53年 9 月第40回日本臨床 外科医学会総会にて発表した。

\section{文盛}

1）胃癌研究会編：胃癌取扱い規約，金原出版，東 京, 1976.

2）村田原庸，佐久間 晃：胃癌の進展に関する組 織計測学的研究, 特に II 型早期胃癌の進展につ いて, 日消外誌, $73: 1169 ， 1976$.

3）佐野量造：胃疾患の 臨床病理, 医学書院, 東 京, 1974 .

4）西沢 護, 野本一夫, 間山素行他 : 小弯線上の 線状潰瘍に随伴した II c + II 型早期胃癌, 胃と 腸, $8: 1077,1973$.

5）仁㼛善郎，平山廉三，宮永忠彦他 : 早期胃癌の 病理組織学的検討一とくに高分化型と低分化型 を合併せる混合型について，第13回日本消化器 外科学会総会 (熊本). 1979.

6) 村上忠重 : 早期胃癌と線状潰瘍の共存症例群を 見て，胃と腸，8：1013，1973.

7）胃がん研究会, 国立がんセンター：全国胃がん 登録調查報告，第12号，昭和48年度症例, 1978.

8）小黒八七郎，崎田隆夫： pm 胃癌之内視䭗診 
断. 胃と腸, $11: 869,1976$.

9）忍田䔆吾, 西田一巳 : 幽門部 I c $c+\mathbb{I I}$ 型早期胃 癌の 1 例，胃之腸，6：1042，1971.

10）池田 誠：II c + II 型早期胃癌を疑わせた幽門 部病变, 胃之腸, $6: 1044,1971$.

11) Menuck, L.: Transpyloric Extension of Gastric Carcinoma. Digestive Diseases, 23: 269, 1978.
より引用。

12) Brinton, W.: Lecture on Disease of the Stomach, 2nd ed. Churchill, London, 1965.

13）石井俊世：胃癌の十二指腸進展に関寸る臨床病 理学的研究, 長崎医学会誌, $50: 211,1975$.

14）石川羊男：胃癌の十二指腸進展に関する臨床病 理組織学的研究, 日外会誌, $72: 622,1971$. 